\title{
Strategy and Learning Motivation of Students in Education Management Major
}

\author{
Saryanto $^{1,2, *}$, Asri Budiningsih ${ }^{1}$, Husaini Usman ${ }^{1}$, Alisa Alfina ${ }^{3}$, Rosyida Nurul Anwar ${ }^{3}$ \\ ${ }^{1}$ Department of Educational Management, Postgraduate of State University of Yogyakarta, State University of Yogyakarta, Indonesia \\ ${ }^{2}$ Department of Mathematics Education, Faculty of Teacher Training and Education, University of Alma Ata Yogyakarta, Indonesia \\ ${ }^{3}$ Early Childhood Education Program, Faculty of Teacher Training and Education, University of PGRI Madiun, Indonesia
}

Received June 20, 2020; Revised August 22, 2020; Accepted September 11, 2020

\section{Cite This Paper in the following Citation Styles}

(a): [1] Saryanto, Asri Budiningsih, Husaini Usman, Alisa Alfina, Rosyida Nurul Anwar, "Strategy and Learning Motivation of Students in Education Management Major," Universal Journal of Educational Research, Vol. 8, No. 11, pp. 5178-5182, 2020. DOI: 10.13189/ujer.2020.081117.

(b): Saryanto, Asri Budiningsih, Husaini Usman, Alisa Alfina, Rosyida Nurul Anwar (2020). Strategy and Learning Motivation of Students in Education Management Major. Universal Journal of Educational Research, 8(11), 5178-5182. DOI: 10.13189/ujer.2020.081117.

Copyright $\bigcirc 2020$ by authors, all rights reserved. Authors agree that this article remains permanently open access under the terms of the Creative Commons Attribution License 4.0 International License

\begin{abstract}
Students who have good motivation will not do things that are prohibited or that are not justified. Even they try to do their best and do various ways to be able to improve their knowledge both in the area of campus and outside of campus. However, not all students have either intrinsic or extrinsic encouragement. This study is aimed to find out and describe the forms of motivation, learning strategies, and factors that influence student's motivation in learning at the Department of Education Management. The research method is mixed-methods. Quantitative data is the instrument Motivated Strategies for Learning Questionnaire (MSLQ). This questionnaire was given to 100 samples, which were students in the Department of Education. Qualitative data were collected through semi-structured model interviews with several students. The results show that the forms of students' motivation in the Department of Education are intrinsic and extrinsic motivation. Students' learning strategies cover practice, elaboration, organization, critical thinking, self-regulation, learning time and place, learning arrangements, group learning, and seeking assistance. Then, the factors that influence students' motivation and learning strategies are intrinsic and extrinsic encouragement. Besides, factors influencing learning strategies and motivation are learning media, learning resources, timing and place of learning, grades and achievement index, understanding material repeatedly, cooperation both positive and negative in
\end{abstract}

completing the task, and discussion.

Keywords Strategy, Learning, Motivation, Education Management

\section{Introduction}

Education is one of the media serving as a place for the learning process. The teaching and learning process has the aim to make students at pre-school, elementary, secondary, and higher levels such as in higher education to be able to acquire and improve the knowledge has been learned $[1,2]$. To achieve these goals, students must show a strong passion and desire. These desires can generally originate from within students, and they can also come from outside themselves or around students. Desire or enthusiasm is divided into desires that come from internal and external sources of students. This internal or external source is called motivation. Motivation is something that can encourage and foster one's desire to do something. This impulse makes a person want to fulfill their wishes and desires [3]. Internal motivation is an encouragement that comes from within students leading them to try in fulfilling their interests and desires in order to gain knowledge and achieve success in learning. This motivation can be 
"interest and curiosity or curiosity" [4].

It points out that motivation encourages students to learn well and indeed because they want to get better grades, sufficient knowledge, and success from such earnest endeavors. Besides, students also get extrinsic motivation, namely all forms of encouragement originating from outside the students themselves and which causes them to strive to learn and try earnestly to get the influence that comes from outside themselves. This motivation can be in the form of encouragement that arises because of the gifts for successful students, the benefits of knowledge have been obtained if studying diligently and hard, and good work if getting a very satisfying score. Good motivation comes from motivation in (intrinsic) or those who come from outside (extrinsic) of the students. Thus, a student will get success in carrying out the process of education and teaching. This success will appear by itself if a student can find out the benefits of encouragement available at the level of education he/she is following.

One of the educational processes in question is in a college. College is one place where students follow the process of education and learning to obtain, improve, and implement science in the future. College, as the highest education provider, is expected to provide significant benefits for students by always improving quality in the fields of education and teaching, research, and community service [5]. Dealing with three cases, the learning process in college can affect the motivation that exists in the students. With the quality of education, research, and community service, then all of these things can be applied to the improvement and development of teaching and learning in college. Thus, encouragement caused by things from outside students can arise by themselves because they want to get good knowledge from the college and get prizes and good jobs in the future. In addition to work, prizes, or extrinsic motivation, students also have encouragement that naturally comes from within themselves. Internal motivation is a natural desire that supports them to come, learn, and try seriously.

Students who have good motivation will not do things that are prohibited or that are not justified. Even they try to do their best and do various ways to be able to improve their knowledge both in the area of campus and outside of campus. However, not all students have either intrinsic or extrinsic encouragement. Based on observation and interview conducted by researchers on students from the Tarbiyah Department of the State Islamic High School (STAIN) Kerinci, various problems exist within students related to the motivation they have. One of the problems found is that some students are forced to take classes or not because of their desire.

Besides, some students take classes just to get grades and put aside the knowledge given by the lecturer. The students are less concerned with science but have various efforts to get high grades. Another problem found in some students does not have the inner and outer encouragement to attend lectures. They also do not have a strategy or a better way to get knowledge on campus. The students only attend lectures due to they have no other choice. They could not explain the encouragement behind them able to follow the learning process in STAIN Kerinci. Based on these problems, the researcher assumes that many good students have good motivation and learning strategies and who do not have good motivation and learning strategies. Hence, researchers want to see the impulses that exist in the students and discover the strategies used to gain and improve knowledge so that both their motivation and learning strategies can be better.

\section{Method}

The type of research used is multiple research methods (mixed methods). Cresswell \& Clark [6] point out that mixed methods are a series of procedures in collecting, analyzing, and combining both quantitative and qualitative approaches in a study or series of studies to be able to answer research questions. The study was conducted using the MSLQ questionnaire and interview. It shows that this study has a series or procedure of research that starts from quantitative data collection from the results of filling out the questionnaire, and subsequently, qualitative data from the results of the interview. The population and sample used as research subjects were 100 students in the English Education Study Program. The questionnaire used was a Motivated Strategies for Learning Questionnaire (MSLQ).

The questionnaire compiled by Pintrich et al. (1991) consisted of 82 statements with Likert scale 1, 2, 3, 4, 5, 6, and 7, where the number 1 started from very incorrect to number 7, which is very true. MSLQ consists of two parts, namely: 1) the Motivation section, and 2) the Learning Strategies section. The motivation section consisted of 31 statements and was used to test research subjects related to the goals and beliefs on the course, the ability to take and complete lectures, and worries in taking the exam. The learning strategy section consisted of 31 statements about the implementation of various cognitive and meta-cognitive strategies. This section also consisted of 16 statements to measure ability in various ways.

The validity and reliability of MSLQ have been carried out by Pintrinch et al. [7] by researching 380 students as research samples. First, the researchers completed the factor analysis to determine the use of the analysis model and the process of using the scale of MSLQ. The factor of the resulting analysis consists of motivational factors and learning strategy factors. Furthermore, the researcher calculated the internal reliability number (Cronbach's alpha) and the zero correlation between the motivation and cognitive scales. In general, Cronbach's alpha obtained was more significant than .70 , but the rest below .70 , which was .52. Overall, Cronbach's alpha shows that MSLQ had good internal validity and reliability. Data collected from 
the questionnaire were analyzed quantitatively using descriptive statistics to describe the data without making conclusions or decisions from the data. After the data had been calculated, the data are transferred to the table. Then, the data as described follow what had been displayed. To increase the level of clarity of data processing results, the researcher presented a diagram based on the previous table [8]. Whereas interview data were analyzed qualitatively using the miles and Huberman models.

\section{Findings}

The analysis section will be presented research findings from questionnaire items. Besides, the results are presented in tables, descriptions, and diagrams. The last part of this analysis is the exposure to the results of the interview relating to factors that influence students' motivation and learning strategies.

\subsection{The Forms of Motivation and Student Learning Strategies}

\subsubsection{Motivation}

The motivation scale consists of several components. The first component is a core component consisting of intrinsic goals, extrinsic goals, and assignment grades. Another component is the expectation component, which consists of confidence in supervision and self ability. Also, there is an effective component consisting of concerns about the exam. The table below is a category of motivation scale and sub-scale of the scale.

Table 1. Motivation Scale

\begin{tabular}{|c|c|c|c|}
\hline Scale & Dimension & Sub Scale & Item \\
\hline \multirow{6}{*}{ Motivation } & \multirow{3}{*}{$\begin{array}{c}\text { Value } \\
\text { Components }\end{array}$} & Intrinsic Purpose & $1,16,22,24$ \\
\hline & & $\begin{array}{l}\text { Extrinsic } \\
\text { Purpose }\end{array}$ & $7,11,13,30$ \\
\hline & & $\begin{array}{l}\text { Assignment } \\
\text { Value }\end{array}$ & $\begin{array}{c}4,10,17,23 \\
26,27\end{array}$ \\
\hline & \multirow{2}{*}{$\begin{array}{l}\text { Expectation } \\
\text { Components }\end{array}$} & Control Belief & $2,9,18,25$ \\
\hline & & Personal Ability & $\begin{array}{c}5,6,12,15,20 \\
21,29,31\end{array}$ \\
\hline & $\begin{array}{c}\text { Affective } \\
\text { Components }\end{array}$ & $\begin{array}{l}\text { Worries towards } \\
\text { Exam }\end{array}$ & $3,8,14,19,28$ \\
\hline
\end{tabular}

The item below is one of the statements of Intrinsic Objective Orientation. The analysis conducted on this item is to discover the frequency $(\mathrm{F})$ and percentage $(\mathrm{P})$ of the answers given by respondents.

Table 2. Frequency and Percentage of Items 1

\begin{tabular}{|c|c|c|}
\hline & $\begin{array}{c}\mathrm{F} \\
(\mathrm{n}=100)\end{array}$ & $\begin{array}{c}\mathrm{P}(\%) \\
(\mathrm{n}=100)\end{array}$ \\
\hline Less right & 7 & 7.0 \\
\hline Neutral & 11 & 11.0 \\
\hline Correct & 34 & 34.0 \\
\hline More Correct & 36 & 36.0 \\
\hline Strongly Correct & 12 & 12.0 \\
\hline
\end{tabular}

In this item, it can be seen that there are 36 respondents (36\%) state that they like challenging material during the class because the challenging material can make them obtain new things. Of all the respondents, there are 12 respondents $(12 \%)$ who argue that this is an exact thing. This means that more respondents say this is true. Based on the static results, there are no respondents $(0 \%)$ who assert that the statement is not valid. There are 7 respondents $(7 \%)$ who argue that this is not entirely true. This is logical by considering the class, some students like challenging material, but they do not learn new things. Besides, some students do not like challenging material, but they learn new things. Both of these possibilities can occur as variations in the class. To see this item more clearly, the diagram below gives a clearer picture.

Based on the diagram, it can be ascertained that the frequency and percentage have been dominated by respondents who have answered that the statement is right compared to respondents who have answered the statement as standard and not right.

\section{Di kelas, saya lebih suka materi yg menantang sehingga saya dapat} mempelajari hal baru

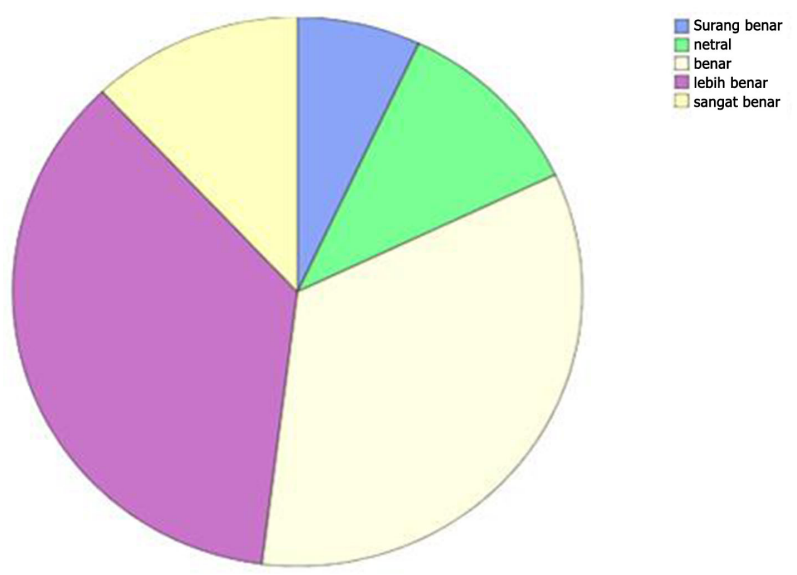

\section{Discussion}

Learning strategies and motivation have a very close relationship. These two essential elements simultaneously influence each other. Students who have high motivation will implement various strategies in order to master the lecture material or can complete lecture assignments. In other words, motivation encourages students to be able to make excellent and orderly planning so that they can formulate appropriate goals in implementing learning strategies [9]. This linkage can also be seen from the result of the MSLQ questionnaire analysis and semi-structured model interview with students of semester IV at the Department of Tarbiyah State Islamic High School (STAIN) Kerinci 2013/2014 academic year.

The above analysis states that there is a relationship between motivation and student learning strategies. Each scale (motivation and strategy) has a form or model 
obtained from the response that has been given. First, the form of motivation "challenging and difficult material can increase knowledge" is one form of intrinsic motivation. Challenging material is a perception and perspective of someone who sees that there is a material that feels challenging or difficult. This perception comes from within the person so that motivation is included in intrinsic motivation [10]. Considering the motivation, the encouragement that arises in students is to find and implement appropriate strategies in order to master the challenging material. One of the strategies applied is through practice, which is "continuously repeating material" and "making use of small notes, summaries, and keywords" during learning. Another form of motivation is "getting a grade / high grade / GPA (IP) in the class." This form is extrinsic motivation because, with a plan to get a high grade or IP, students will study hard [11]. To achieve the intended score or IP, the form of strategy that needs to be applied is by practice, expansion, organization, critical thinking, self-regulation, timing and place of learning, learning arrangements, group learning, and asking for help from other friends in learning [7].

In general, the forms of motivation possessed by students consist of intrinsic motivation, extrinsic motivation, material values, learning beliefs, self-confidence, and worries in the exam. Intrinsic motivation consists of material that is challenging to get new things; the problematic material is to add knowledge, understanding the material in-depth, earnest in doing the task. Extrinsic motivation consists of high grades or IP in class, the best thing in class as pride. The motivation of material values consists of the ability to connect a variety of material or courses, understanding of relevant lecture material, passions for the material, lecture topics. The motivation of learning beliefs consists of mastering material that comes from good learning or crafts, understanding of the material that comes from the seriousness of learning.

Self-motivation motivation consists of the belief in getting the highest IP, the belief in understanding the basic concepts and skills of challenging material, the confidence in making assignments and taking lectures and examinations well, the belief in doing the best in class. Concerns in the exam consist of the ability to take the exam when it is compared to other friends, Concentration on each question in the exam, Feelings are aimed at the success of the exam, Feelings of pleasure, cheerful, uplifting, and optimistic during the exam. Students' learning strategies consist of practice, elaboration, organization, critical thinking, self-regulation, learning time and place, learning arrangements, work in pairs, and seeking help. The training strategy consists of reviewing the material continually, understanding the material with crucial words, small notes, and summaries.

The elaboration strategy consists of expanding knowledge through lectures, discussions, books, and articles, understanding material through synchronization. The organizational strategy consists of using outlines in books or materials, understanding material by reading, utilizing tables, diagrams, and graphs in understanding material. Critical thinking strategies consist of questions about what is read and heard, collection of real evidence from the topics explained by the lecturer, the development of own ideas in attending lectures, the use of conclusions in other ways. Self-regulation strategies consist of a concentration to the explanation of lecturers and personal discussion in reading and repetition of material. The use of other ways to understand difficult material is by giving questions about the ability to understand lecture material on oneself, changes in learning methods such as the model applied by lecturers.

They understand the material only by reading the core topics, Preparing a schedule or a good study schedule, Simplifying the lecture notes to be easily understood. The strategy of time and place of learning consists of utilizing a special place to concentrate on the material, proper use of time to study, and attend lectures. Learning management strategies consist of crafts and neatness in lectures, efforts in understanding difficult material. The paired learning strategies consist of explaining lecture material to friends, collaboration, and discussion in understanding and completing college assignments. The strategy of seeking help consists of learning and completing assignments without the help of others, asking questions to lecturers and friends about lectures. Learning strategies and motivation both have essential functions in determining student learning success. Learning strategies have an essential role in improving learning abilities and outcomes $[12,13]$. Besides, motivation is part of feeling and implemented in action, which can trigger itself, so that it has a strong encouragement to learn and achieve the goals set by each individual [14]. The equation function of strategy and learning motivation is that the two scales must be attached to students so that there is an encouragement to find and implement the positive value of various strategies for the students.

\section{Conclusions}

The conclusion that can be drawn in the form of strategy and motivation to study in the fourth semester of the Tarbiyah Department of State Islamic High School (STAIN) Kerinci is varied, and it is interrelated to each other. The forms of strategy are practice, elaboration, organization, critical thinking, self-regulation, time and place of learning, learning arrangement, learning in pairs, and seeking help. Meanwhile, the forms of motivation are intrinsic motivation, extrinsic motivation, material values, learning beliefs, self-confidence, and concerns in learning. The factors influencing learning strategies and motivation are learning media, learning resources, timing and place of 
learning, grades and achievement index, understanding material repeatedly, cooperation both positive and negative in completing the task, and discussion.

\section{REFERENCES}

[1] Ramadhan, S., Sumiharsono, R., Mardapi, D., \& Prasetyo, Z. K. (2020). The Quality of Test Instruments Constructed by Teachers in Bima Regency, Indonesia: Document Analysis. International Journal of Instruction, 13(2). doi: 10.29333/IJI.2020.13235A

[2] Sofyan, H., Hartati, S., Anggereini, E., Muazzomi, N., \& Ramadhan, S. (2020). Developing e-module local wisdom based for learning at kindergarten In Jambi, Indonesia. Elementary Education Online, 19(4), 2074-2085.

[3] Brophy, J. E. (2017). Fostering student learning and motivation in the elementary school classroom. In Learning and motivation in the classroom (pp. 283-306). Routledge.

[4] Wlodkowski, R. J., \& Ginsberg, M. B. (2017). Enhancing adult motivation to learn: A comprehensive guide for teaching all adults. John Wiley \& Sons.

[5] Setiawan, J,K., Sahabuddin, C., \& Ramadhan, S. "The Role of Parents on the Character Education of Kindergarten Children Aged 5-6 Years in Bima." Universal Journal of Educational Research. 8 (3): 779-84. 2020

[6] Cresswell, J. W., \& Plano Clark, V. L. (2011). Designing and Conducting Mixed Method Research (2nd ed.).
Thousand Oaks, CA: Sage.

[7] Pintrich, P. R., Smith, D. A. F., Garcia, T., \& McKeachie, W. J. (1993). Reliability and predictive validity of the Motivated Strategies for Learning Questionnaire (MSLQ). Educational and Psychological Measurement, 53, 801-813.

[8] Denscombe, Martyn. (2007). The Good Research Guide for Small-Scale Social Research Projects (3rd ed). Berkshire: The McGraw-Hill Companies.

[9] Anni, Catarina Tri. (2004). Psikologi Belajar. Semarang: UPT UNNES Press.

[10] Pujadi, Arko. 2007. Faktor-faktor yang mempengaruhi motivasi belajar mahasiswa: studi kasus pada Fakultas Ekonomi Universitas Bunda Mulia. Business and Management Journal Bunda Mulia, Vol. 3, No. 2, September 2007.

[11] Sardiman, AM. (2001) Interaksi dan Motivasi Belajar Mengajar. Jakarta: Rajawali Pers.

[12] Lai, Ying-Chun. (2009). Language learning strategy use and English proficiency of university freshmen in Taiwan. TESOL Quarterly, 43(2), 255-280.

[13] Li, Jie, \& Chun, Cecilia Ka-wai. (2012). Effects of learning strategies on student reading literacy performance. Reading, 12(1).

[14] Zimmerman, B. J. (2000). Attaining self-regulation: A social cognitive perspective. In M. Boekaerts, P. R. Pintrinch \& M. Zeidner (Eds.), Handbook of self-regulation (pp. 13-39). San Diego, CA: Academic Press. 